\title{
韓·中경계지역 문화유산을 이용한 박물관 전시구축의 교육적 활용 Approaches to Education Programs and Exhibition Contents of the Museum Using Cultural Heritage in Korea and China Border Areas
}

\author{
오일환 \\ 경희대학교 학부대학 \\ II-Whan Oh(ohil@khu.ac.kr)
}

\section{요약}

문화유산은 민족의 삶과 지역성을 함축하고 있는 역사적 상징이다. 한중경계의 압록강과 두만강 지역에 는 다양한 민족의 문화유산이 분포하고 있다. 이에 한중간의 경계에 분포하고 있는 문화유산에 대한 연구 는 우리 민족의 정체성과 역사적 문화의식을 확립하고 이를 교육적으로 활용하기 위해서 매우 중요하고 시급한 연구과제이다. 그러나 중국이 고구려의 문화유산을 세계문화유산으로 등재하고 동북공정을 본격적 으로 추진하면서 고구려와 발해 뿐 아니라 조선시대와 근현대의 역사문제와 문화유산을 둘러싸고 우리나 라와 갈등을 야기하고 있다.

본 연구는 한중경계지역의 문화유산에 대하여 문헌학적인 연구보다는 박물관에서 시각적인 자료활용과 교육학습의 연계를 위하여 문화사적 인문경관의 전시콘텐츠 구축과 이를 활용한 교육적 학습방안을 찾아 보았다. 이러한 연구결과를 통하여 근대국가에 대한 영토인식 뿐 아니라 세계문화유산에 대한 중요성을 인식할 수 있으며 동북공정에 대한 실질적인 이해를 학습할 수 있다. 그리고 웹이나 앱의 구축을 통한 역사 문화 관광자원으로 활용할 수 있을 뿐 아니라 박물관의 전시자료를 활용한 학습프로그램에 따라 동북지역 에 대한 한중간의 문화적 특징을 이해할 수 있다.

중심어 : | 한중경계지역 | 문화유산 | 동북공정 | 백두산정계비 | 박물관전시 |

\section{Abstract}

Cultural heritage is the historic symbol implying the life of people and regionality. Accordingly, the study on cultural heritage along the border between Korea and China is a very critical and urgent task for educational purposes as well as to secure historic and cultural awareness and national identity. The border area between Korea and China is classified into the areas along Aprok River and areas along Tumen River where the cultural heritage of various ethnicities is scattered.

Accordingly, this study tried to find the approaches to implement and use the exhibition contents for educational purposes as well as visual applications rather than a literary study on cultural heritage in the border area between Korea and China. The results of this study will be the opportunity to enhance the practical understanding of the modern states as well as to learn the cultural awareness of the territory of a modern state and people's awareness of the importance of world heritages. Furthermore, the results of this study will be used as the resources for historic and cultural tours on the web or applications and help to understand the cultural features of Korea and China in the northeastern region as well as historic awareness in educational programs using exhibition materials in a museum.

- keyword : | Border Area between Korea and China | Cultural Heritage | North-East Project | Mt. Baekdu Border Stele | Museum Exhibition I

접수번호 : \#101005-002

접수일자 : 2010년 10월 05일
심사일자 : 2011년 01월 17일

교신저자 : 오일환, e-mail : ohil@khu.ac.kr 


\section{I. 서론}

우리나라와 중국은 역사와 문화적으로 매우 밀접한 관계이다. 또한 한중경계의 압록강과 두만강 지역은 우 리 민족의 문화유산이 다양하게 분포하고 있다. 압록강 지역은 대부분 고구려와 조선시대의 문화유산이 산재 하고 있으며 두만강은 발해와 근현대 문화유산이 많다.

그러나 중국이 전면적인 개방정책과 동북공정을 추 진하면서 고구려와 발해의 문화유산을 세계문화유산으 로 등재하면서 우리나라와 역사문화의 정통성 문제로 갈등을 야기하고 있다[1].

국내에서 한중경계지역에 대한 연구는 고구려연구재 단(현 동북아역사재단)이나 국사편찬위원회를 비롯한 연구기관과 전문가를 중심으로 고구려와 발해 뿐 아니 라 백두산정계비 및 간도영유권 등에 대한 문헌학적 연 구가 활발히 진행되어 왔다[2].

또한 근래에는 한중이나 한일간의 영토문제와 관련 하여 박물관에 소장되어 있는 고지도를 활용한 문화유 산 전시콘텐츠에 대한 연구가 시작되고 있다[3]. 그러나 한중간의 경계에 분포하고 있는 문화유산을 이용한 박 물관의 경관전시콘텐츠 구축과 이를 활용한 연구는 찾 아보기 쉽지 않다[4].

이러한 인식에서 본 연구의 목적은 기존의 박물관 전 시에서 왕조나 시대 중심의 구분이 아니라 압록강과 두 만강지역에 산재하는 우리 민족 문화유산을 대상으로 문화사적 인문경관의 전시콘텐츠를 구축하고 이를 활 용한 교육적 학습방안을 제시하고자 하였다.

이에 연구방법으로 국내의 박물관에 전시되었던 고 구려와 발해를 비롯한 한중문화유산의 전시현황과 그 한계점을 2장에서 살펴보았다. 3장에서는 학생을 대상 으로 국가에서 발행하는 가장 공신력이 있는 중고등학 교 '국사'교과서에 사용하고 있는 시각자료의 현황을 정 리하였다.

이러한 분석을 바탕으로 연구범위는 압록강과 집안 지역의 고구려관련 문화유산과 백두산을 비롯한 두만 강과 간도에 대한 발해 및 생활터전의 문화유산에 대한 인문경관적인 전시콘텐츠 구축과 교육적 활용방안으로 한정하였다.
앞으로 문화유산에 대한 연구는 민족의 삶과 지역성 을 함축하고 있는 역사적 상징성으로 점차 연구의 필요 성이 증가할 것이다. 따라서 이에 대한 연구는 역사의 왜곡을 방지하고 민족의 정체성과 역사적 문화의식의 확립을 위한 매우 시급하고 중요한 연구과제의 하나이 다.

\section{II. 국내 박물관의 전시현황과 한계점}

우리나라의 박물관은 국공립, 사립, 대학을 포함하여 600여개를 넘고 있다. 1992년 한중수교 이래 국내 박물 관에서는 대규모 전시회 뿐 아니라 상설 전시실을 꾸준 히 설치하고 있다.

그러나 한중경계지역의 문화유산에 대한 박물관 전 시는 정치적이고 지리적인 한계로 인하여 활발하게 이 루어지고 있지 않다. 이러한 상황에서 주요 현황을 아 래와 같이 [표 1]로 정리하였다.

\section{표 1. 국내박물관의 한중경계지역 문화유산의 전시현황}

\begin{tabular}{|c|c|c|}
\hline 기관 & 전시명칭 & 내 용 \\
\hline $\begin{array}{l}\text { 국립중앙 } \\
\text { 박물관 }\end{array}$ & 고구려실 & $\begin{array}{l}\text { 우리나라 최초의 상설전시관 고구 } \\
\text { 려의 출현, 문화 성격과 의식, 영역 } \\
\text { 확장, 한강유역 이남의 발굴조사 성 } \\
\text { 과, 불교사상과 예술을 소주제로 구 } \\
\text { 성 }\end{array}$ \\
\hline 격기도 & $\begin{array}{l}\text { 우리 결의 고구려 } \\
\text { (2005) }\end{array}$ & $\begin{array}{l}\text { 경기도의 임진강과 한강 유역의 } \\
\text { 고구려 유적과 국내의 학술조사 보 } \\
\text { 고서 및 저서와 논문 등의 성과와 } \\
\text { 체험 }\end{array}$ \\
\hline $\begin{array}{l}\text { 서울역사 } \\
\text { 박물관 }\end{array}$ & $\begin{array}{l}\text { 대륙의 꿈 고구려전 } \\
\text { (2005) }\end{array}$ & $\begin{array}{l}\text { 북한의 평양 조선중앙역사박물관 } \\
\text { 이 소장한 고구려 유물을 전시. 고 } \\
\text { 분과 왕궁의 모형, 고구려 벽화 모 } \\
\text { 사, 고구려인의 삶 영상물 구성. 환 } \\
\text { 도산성·오녀산성 발굴보고서 등 }\end{array}$ \\
\hline \multirow[b]{2}{*}{$\begin{array}{l}\text { 서울대학교 박 } \\
\text { 물관 }\end{array}$} & $\begin{array}{l}\text { 하늘에서 본 고구려 } \\
\text { 와 발해" (2008) }\end{array}$ & $\begin{array}{l}\text { 우리나라 최초로 위성사진과 항공 } \\
\text { 사진으로 고구려와 발해의 대표적 } \\
\text { 인 유적 전시. 중국, 북한, 남한의 } \\
\text { 고구겨와 방해 어적에서 출토 유물 } \\
\text { 과 광개토왕릉비 탁본, 각종 유적모 } \\
\text { 형 }\end{array}$ \\
\hline & $\begin{array}{l}\text { 고구려-한강유역의 } \\
\text { 고구려 애새 } \\
\text { (2000), 역사와 의 } \\
\text { 식-고구려의 숨결을 } \\
\text { 찾아서(2000), 한 } \\
\text { 일대학 최초의 교류 } \\
\text { 전-해동성국 발해 } \\
\text { (2003) }\end{array}$ & $\begin{array}{l}\text { 국내에서 유일하게 발해 유물을 소 } \\
\text { 상하고 있는 기관으로 한강유역의 } \\
\text { 고구려 유적을 발굴, 조사하여 국내 } \\
\text { 고구려 연구의 기틀을 마련 }\end{array}$ \\
\hline
\end{tabular}




\begin{tabular}{|c|c|c|}
\hline $\begin{array}{l}\text { 성균관대학교 } \\
\text { 박물관 }\end{array}$ & $\begin{array}{l}\text { 집안 고구려 유적의 } \\
\text { 어제와 오늘(2006) }\end{array}$ & $\begin{array}{l}\text { 1930-40년대에 촬영된 유리원판 } \\
\text { 사진을 현대의 기술로 복원하여 현 } \\
\text { 재의 모습과 비교 }\end{array}$ \\
\hline $\begin{array}{l}\text { 고려대학교 박 } \\
\text { 물관 }\end{array}$ & $\begin{array}{ll}\text { 한국의 } & \text { Global } \\
\text { Pride } & \text { 고구려 } \\
\text { (2005) } & \end{array}$ & $\begin{array}{l}\text { 북한의 조선 중앙역사박물관 유물 } \\
\text { 과 일본의 유물을 전시 }\end{array}$ \\
\hline $\begin{array}{l}\text { 경희대학교 중 } \\
\text { 앙박물관 }\end{array}$ & $\begin{array}{l}\text { 역사의 숨결 가득한 } \\
\text { 고구려 와당(2005) }\end{array}$ & $\begin{array}{l}\text { 고구려 와당을 형태와 특징으로 분 } \\
\text { 류하여 전시 }\end{array}$ \\
\hline $\begin{array}{l}\text { 경희대학교 혜 } \\
\text { 정박물관 }\end{array}$ & $\begin{array}{l}\text { 영토의 경계 삶의 흔 } \\
\text { 적(2005) }\end{array}$ & $\begin{array}{l}\text { 고지도와 문헌, 자료, 서양인들의 } \\
\text { 우리나라 견문록 중심- 백두산과 } \\
\text { 압록강 및 두만강 북쪽의 생환무대 } \\
\text { 에 남아 있는 우리 민족의 삶의 경 } \\
\text { 계와 흔적 전시 }\end{array}$ \\
\hline
\end{tabular}

[표 1]에서 살펴 본 바와 같이 국내의 박물관이나 기 관에서는 중국의 동북 3성 지역에 산재한 고구려, 발해 의 문화유산을 비롯한 간도지역의 우리 민족과 관련한 문화유산에 대한 특별전시회를 진행하였다[5]. 그리고 박물관 이외에 방송이나 신문매체를 통하여 '고구려 고 분벽화'(KBS,1994), '집안 고구려고분벽화'(조선일보 사,1993)를 비롯하여 고구려 관련의 전시회와 도록 등 이 있다. 또한 사진과 그림 자료를 이용하여 시각적으 로 구성한 생활사박물관-고구려 생활관'(사계절,2003) 이 있으며 개인의 답사기와 여행기에 대한 출판물과 인 터넷 등의 자료가 산재하고 있다.

그러나 이러한 전시활동은 중국의 고구려와 발해지 역의 문화유산에 대한 유물의 모형이나 벽화의 모사를 비롯한 비슷한 사진과 영상자료를 사용하고 있거나 유 사한 자료를 반복적으로 사용하고 있는 한계에 이르고 있다. 또한 새로운 자료나 기존의 자료를 교육적으로 활용하기 위한 전시콘텐츠의 개발과 구축방안에 대한 연구는 찾아보기 더욱 어려운 실정이다.

\section{III. 박물관의 경관전시 콘텐츠구축과 교육적 활 용방안}

\section{1. 고등학교 국사교과서의 시각자료 현황}

학생들은 교과과정에서 '국사'교과서를 통하여 고구 려와 발해의 역사와 문화를 접하는 경우가 대부분일 것 이다. 특히 국가 기관에서 발행하는 고등학교의 국사는 학생 뿐 아니라 일반인이 학습해야 할 기본적인 지식을 담고 있을 뿐 아니라 가장 표준적인 학습자료를 사용하
고 있다. 이에 고등학교 국사 교과서에 나타난 고구려 발해의 문화유산 관련 시각자료를 [표 2]와 같이 정리 할 수 있다.

\section{표 2. 국사교과서의 고구려 발해 문화유산 시각자료 현황}

\begin{tabular}{|c|c|c|}
\hline 항목 & 제 목 & 쪽 \\
\hline \multirow{3}{*}{ 백두산 } & 천지 사진 & 8 \\
\hline & 정계비 그래픽 & 103 \\
\hline & 정계비부근 지도 & 114 \\
\hline \multirow{8}{*}{$\begin{array}{l}\text { 중국 고구 } \\
\text { 려 유적 } \\
\text { (집안지역) }\end{array}$} & 국동대혈 사진 & 37 \\
\hline & 광개토대왕릉비 사진 & 44 \\
\hline & 국내성 서벽 사진 & 47 \\
\hline & 귀족생활 벽화(각저총) & 136 \\
\hline & 기마전 무사 벽화(삼실총) & 194 \\
\hline & 달의 신 벽화(오회분) & 254 \\
\hline & 장군총 사진 & 261 \\
\hline & 거문고 타는 모습 벽화(무용총) & 266 \\
\hline \multirow{7}{*}{$\begin{array}{l}\text { 북한 고구 } \\
\text { 려 유적 } \\
\text { (안악, 강 } \\
\text { 서지역) }\end{array}$} & 귀족의 모습 벽화(안악3호분) & 134 \\
\hline & 귀족저택의 주방벽화(안악3호분) & 136 \\
\hline & 대행렬도 그래픽(안악3호분) & 196 \\
\hline & 현무도 벽화(강서 대묘) & 257 \\
\hline & 시녀도 벽화(강서 수산리) & 194 \\
\hline & 곡예도 벽화(강서 수산리) & 134 \\
\hline & 수산리 벽화(강서 수산리) & 268 \\
\hline \multirow{3}{*}{$\begin{array}{l}\text { 중국 발해 } \\
\text { 유적 }\end{array}$} & 정혜공주묘 돌사자상(길림 돈화) & 254 \\
\hline & 발해의 석등(흑룡강 영안) & 265 \\
\hline & 상경용천부 평면도 & 264 \\
\hline
\end{tabular}

(국사편찬위원회, 고등학교 국사, 교육과학기술부,2009)

[표 2]를 살펴보면 백두산과 중국 집안지역의 고분과 벽화를 비롯하여 북한의 강서와 안악지역의 벽화에 나 타난 생활모습 그리고 발해의 문화유산은 돌사자상과 석등으로 나타나 있다. 간도지역은 1890년에서 1930년 대의 한민족 해외이주분포지도(236쪽)와 의병의 참여 계층(115쪽) 그리고 간도동포의 생활모습(237쪽)에 불 과한 실정이다.

이외에 직접적인 관련은 없지만 병자호란과 관련한 경기도 광주의 남한산성 북문(92쪽)이나 중국의 사신을 맞이하던 영은문 자리에 세워진 독립문(112쪽), 안중근 이 이토 히로부미를 사살한 기록화(115쪽)가 있다[6]. 이와 같이 고등학교 국사교과서에 나타난 고구려 발 해관련의 문화유산에 대한 시각자료는 매우 한정되고 
있음을 알 수 있다. 그리고 북한에 산재한 고구려 유적 은 '조선유적유물도감'을 대부분 활용하고 있다. 또한 중국에 산재하고 있는 유적에 대한 답사나 자료를 습득 하기 어려움으로 동일한 그림이 사용되는 경우가 많고 사진자료에 대한 설명에서도 명칭만 소개하고 있거나 간단하게 기술하고 있는 한계가 있다.

\section{2. 압록강지역의 경관콘텐츠와 교육적 활용방안}

압록강변의 좁은 지역에서 일어난 고구려는 만주와 요동, 한반도 북부를 차지하는 거대한 제국으로 성장하 면서 천하의 중심으로 생각하였다.

이에 고구려의 고분군과 벽화 광개토대왕릉비에 대 한 사진이나 영상자료를 활용하여 첫째, 살아있는 고구 려 문화를 설명하기 위하여 역사서에 기록된 사료를 바 탕으로 벽화를 통하여 고구려 사람들의 의식세계를 살 펴보도록 한다. 둘째, 집안의 문화유산을 삶의 세계, 광 개토대왕릉비, 고구려의 천도를 통하여 역사와 문화적 인 특징을 파악하도록 한다. 셋째, 조선시대 중국 대륙 과 문물 교류의 창구이었던 연행길 유적과 근현대의 6..25전쟁 유산으로 남겨진 압록강 철교 단교와 항미원 조기념관 등의 압록강 지역에 대한 자료를 활용하여 [그림 1]과 같이 구성한다.

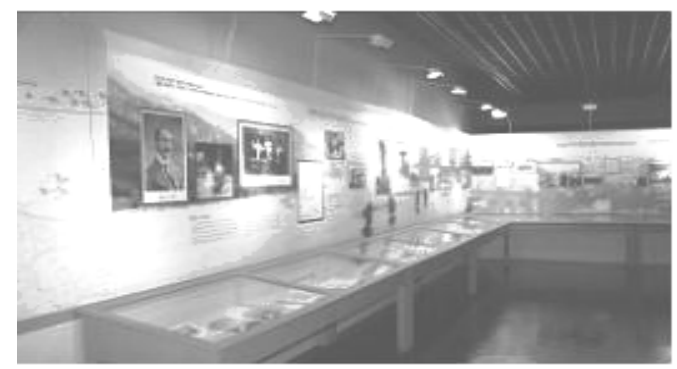

그림 1. 시각자료를 활용한 압록강 지역의 전시구성 예시

1) 역동적으로 살아있는 고구려의 세계관

'삼국지' 동이전의 기록을 바탕으로 고구려의 위치와 국제정세 그리고 고구려의 무용총 벽화 그림을 통하여 역사적 사실과 생활문화를 파악하도록 한다.

이와 함께 고구려의 중심지였던 오녀산성, 국내성, 환 도산성, 평양 등 건국 및 성장과정을 비롯하여 [그림 2]
의 자료를 활용하여 고구려 문화의 역동성을 살펴보도 록 한다.

\begin{tabular}{|c|c|c|}
\hline 주제 & 내용 & 시각자료 \\
\hline \multirow{2}{*}{$\begin{array}{l}\text { 역동적인 } \\
\text { 세계관 }\end{array}$} & $\begin{array}{l}\text { - 고분벽화 분포 } \\
\text { - 복식의 특징 } \\
\text { - 무희의 춤동작 }\end{array}$ & \\
\hline & $\begin{array}{l}\text { - 산악지형과 동물 } \\
\text { - 말과 사냥도구 } \\
\text { - 벽화의 의미 }\end{array}$ & \\
\hline
\end{tabular}

그림 2. 무용총 벽화와 수렵도에 나타난 문화의 역동성

\section{2) 집안의 문화유산}

(1) 삶의 세계

고구려의 역사적 범위를 살펴볼 수 있는 고분은 집안 지역에 하해방, 우산하, 산성하, 만보정, 마선구, 장천 지역의 고분군을 비롯하여 환인의 미창구 고분군이 있 다. 그리고 북한에는 평양, 순천, 평원, 대동, 남포, 온천, 연탄, 은파, 사리원, 안악지역에 76 기의 고분군이 분포 하고 있다.

고분을 통하여 국가의 성립 배경과 특징을 이해하고 [그림 3]과 같이 제시된 시각자료에서 고분의 종류와 분포 및 특징을 살펴 구성한다.

\begin{tabular}{|c|c|c|}
\hline 주제 & 내용 & 시각자료 \\
\hline \multirow{2}{*}{$\begin{array}{l}\text { 문화유산과 } \\
\text { 삶의 세계 }\end{array}$} & $\begin{array}{l}\text { - 고분의 종류 } \\
\text { - 분포와 특징 } \\
\text { - 장군총 }\end{array}$ & \\
\hline & $\begin{array}{l}\text { - } 5 \text { 회분의 특징 } \\
\text { - 시대적 변화 } \\
\text { - 벽화의 특징 }\end{array}$ & \\
\hline
\end{tabular}

그림 3. 고구려의 장군총과 5 회분 모습 비교 예시

(2) 천하의 중심-광개토대왕릉비와 비각 광개토대왕릉비(414)는 1870년 후반부터 알려지기 
시작하면서 비바람의 침식을 막기 위해 1928 년에 2 층 으로 된 비각을 설치했다. 그러나 1976년에 낡아서 붕 괴의 위험이 있다고 하여 철거되었다가 1982년에 대형 비각을 다시 세웠다.

비문을 통하여 영토 확장과정을 연표로 정리하고 지 도에 영역을 그리도록 한다. 그리고 비문의 해석을 통 하여 고구려가 천하의 중심이라는 자부심을 살펴보고 비문에 대한 해석의 차이로 인하여 한중일간에 발생하 는 논쟁의 본질을 [그림 4]의 시각 자료를 활용하여 파 악하도록 한다.

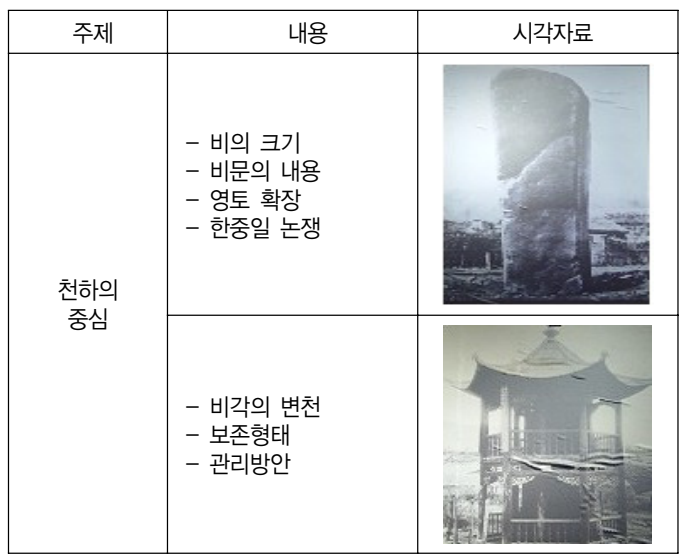

그림 4. 광개토대왕릉 비와 비각 모습

\section{3) 대륙을 연결하는 압록강}

압록강은 우리와 대륙을 갈라놓는 경계로서 혹은 대 륙을 연결해 주는 다리로서 우리의 역사 속에서 중요한 역할을 하였다. 압록강은 백두산이 발원지이며 주변의 지류와 합쳐 서쪽의 황해로 흐르는 길이 $790 \mathrm{Km}$ 의 강이 다. 압록강 철교는 아치가 12 개이고 총길이가 $944 \mathrm{~m}$ 로 1908년 8월에 공사를 착수하여 1911년 10월에 회전 개 폐식으로 준공했으나 1934년 11월에 폐지하였다.

압록강의 유래와 지리적 환경 및 압록강 대교의 형태 와 특징을 비롯하여 [그림 5]의 시각자료를 활용하여 문화적 의미를 살펴보도록 한다.

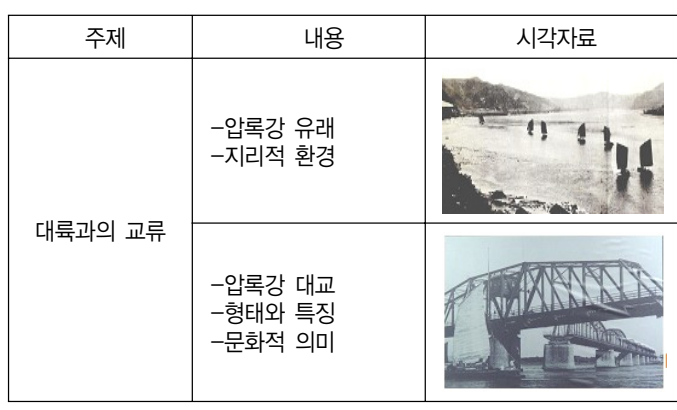

그림 5. 압록강을 운항하는 배와 철교 시각자료

\section{3. 두만강지역의 경관콘텐츠와 교육적 활용방안}

간도지역은 우리 민족의 생활 터전이었다. 일반적으 로 간도는 동간도를 말하며 조선족이 거주하고 있는 훈 춘, 왕청, 화룡을 비롯한 연변자치주를 중심지역으로 2 만 $\mathrm{m}^{2}$ 에 이른다. 또한 간도는 지리적으로 압록강과 송화 강 상류지방인 백두산 지역 일대의 서간도와 두만강 지 역의 동간도, 혼동강 지역의 북간도로 구분할 수 있다.

본래 간도는 함경북도 종성에서 10리쯤 떨어진 두만 강 가운데의 섬을 사잇섬 즉 간도(間島)라고 불렀다고 한다. 그러나 19세기 말부터 우리 민족이 두만강과 압 록강 이북의 비옥한 땅을 개간한 드넓은 지역(墾島)을 의미하게 되었다.

이에 고지도와 문헌에 나타난 간도의 위치를 확인하 고 영토에 대한 개념을 역사의 전개과정에서 이해하도 록 한다. 또한 일본 제국주의가 청과 간도협약을 맺어 우리민족의 생활 터전이었던 간도를 청에 넘겨준 사실 을 파악하도록 한다. 그리고 백두산 정계비의 역사적 의미와 독립운동의 무대이며 민족의 삶의 터전에 대하 여 [그림 6]과 같이 문화사적인 구성한다.

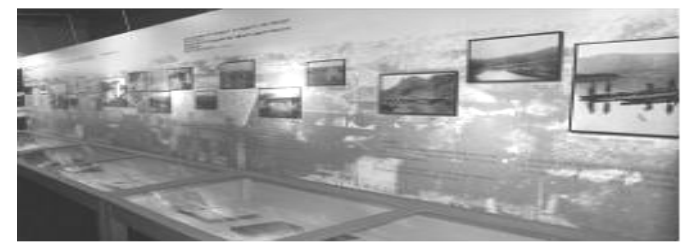

그림 6. 두만강지역의 간도와 발해 문화유산 전시구성 예시

1) 백두산과 정계비

'애국가'에 나오는 백두산은 꼭대기의 화산 분출구 천 
지 주위에 항상 하얀 눈이 덮여 있었기 때문에 마치 흰 머리와 같아 보여 백두산이라 하였다.

청나라와 조선은 백두산을 민족의 발상지로 생각하 면서 분쟁이 발생하였고 이에 경계를 협상하였으나 결 렬되자 산정에 정계비를 세웠다. 백두산 정계비는 1712 년 조선과 청의 영토를 정한 경계비석으로 백두산 천지 의 남동쪽 $4 \mathrm{~km}$, 해발 $2,200 \mathrm{~m}$ 지점에 높이 $72 \mathrm{~cm}$ 크기였 다. 그러나 정계비는 만주사변이 발생한 1931년 9월 전 후에 사라졌다고 하며 현재는 사진과 탁본 자료만 남아 있다[7]. 이에 백두산과 정계비에 대하여 [그림 7]과 같 이 시각자료를 활용한다.

\begin{tabular}{|c|c|c|}
\hline 주제 & 내용 & 시각자료 \\
\hline \multirow{4}{*}{$\begin{array}{l}\text { 백두산과 } \\
\text { 정계비 }\end{array}$} & $\begin{array}{l}\text {-백두산 유래 } \\
\text {-지리적 환경 } \\
\text {-지도사적 특징 }\end{array}$ & \\
\hline & $\begin{array}{l}\text {-민족문화적 의미 } \\
\text {-현대지도와 비교 }\end{array}$ & \\
\hline & $\begin{array}{l}\text {-정계비 유래 } \\
\text {-비문건립 과정 } \\
\text {-비문 내용 }\end{array}$ & \\
\hline & $\begin{array}{l}\text {-정계비 의미 } \\
\text {-한중일 관계 }\end{array}$ & \\
\hline
\end{tabular}

그림 7. 백두산 고지도(보물제1598호)와 정계비

\section{2) 간도의 지리적 환경과 삶의 터전}

(1) 삶의 터전- 간도

역사적으로 고구려와 그 뒤를 이은 발해의 땅으로서 오랫동안 우리 민족의 활동무대였다. 그러나 중국에서 청나라가 건국하면서 출입금지의 봉금정책(1667)을 취 하였고 정계비를 세워 국경선을 확정하고자 하였다.

이 후 청나라가 적극적으로 간도에 대한 이주장려와 개간정책을 취하자 조선에서는 간도를 관리하면서 이 중하를 파견하여 2차례(1885년 을유감계,1887년 정해감
계)에 걸쳐 회담하였지만 토문강에 대한 이견으로 국경 선을 확정하지 못하였다. 이에 조선은 이범윤을 북변간 도관리사로 임명하여 조선인의 호구 및 토지조사와 조 세를 부과하는 등 실질적 보호정책을 취하였다.

이러한 역사적 배경과 사건에 대한 명확한 이해를 위 하여 생활사적인 시각자료를 적절하게 활용한다[8].

\section{(2) 삶의 공동체 생활}

우리 민족은 17 세기부터 수십호씩 간도지역에 대한 정착이민을 시작하였으며 1860년대부터는 조선 관리들 의 수탈, 잇따른 흉년, 천주교에 대한 박해 등을 피하여 압록강 연안에는 이미 20여 군데의 우리 민족의 마을이 생겨났다. 또한 청나라가 만주지역에 대한 봉금을 해제 (1881)하면서 연변지역에 대한 농업 이민이 급격하게 증가하였다.

그리고 1910년 일제의 국권 강탈을 전후하여 국내에 서의 의병투쟁이 어려워지자 많은 애국지사들이 간도 와 러시아지역의 연해주로 망명하였고 일제의 경제 수 탈로 삶의 터전을 상실한 농민들도 이주해 수많은 한인 촌이 건설되어 이미 백만 명을 넘었다[9].

1920년대 유행하였던 '신아리랑'의 의미를 살펴보고 전형적인 조선인 마을이었던 용정의 모습과 생활모습 자료를 활용하여 구성한다. 이와 함께 윤동주 시를 활 용하여 민족교육에 대한 모습을 파악하도록 한다. 이러 한 역사적 사실을 [그림 8]과 같이 시각자료를 활용하 여 구성한다.

\begin{tabular}{|c|c|c|}
\hline 주제 & 내용 & 시각자료 \\
\hline \multirow{3}{*}{$\begin{array}{c}\text { 간도의 삶과 } \\
\text { 민족공동체 } \\
\text { 생활 }\end{array}$} & $\begin{array}{l}\text { - 삶의 터전 } \\
\text { - 간도 유래 } \\
\text { - 지리적 위치 }\end{array}$ & \\
\hline & $\begin{array}{l}\text { - 삶의 공동체 } \\
\text { - 간도 생활 } \\
\text { - 민족문화보전 }\end{array}$ & \\
\hline & $\begin{array}{l}\text { - 민족교육 } \\
\text { - 학교건립 } \\
\text { - 독립운동터전 }\end{array}$ & \\
\hline
\end{tabular}

그림 8. 간도의 삶과 민족의 공동체 생활 
3) 독립투쟁과 민족문화의 계승

(1) 간도협약과 독립투쟁

일본 제국주의는 을사조약(1905)으로 간도지역에 통 감부 파출소를 설립(1907)하였다. 이후 러일전쟁에서 청과 간도협약(1909)을 맺어 만주의 철도부설권과 탄광 채굴권을 부여받고 간도를 청나라로 넘겨주었다.

이로 인하여 우리 민족은 거주 지역을 제한받는 등 실질적인 권리를 행사하지 못하였다. 이주한 우리 민족 은 간도의 각지에서 삶의 터전을 마련하고, 학교를 세 우고 민족교육을 실시하면서 독립운동의 터전으로 삼 았다. 민족지도자들은 만주와 연해주에서 무장독립활 동과 독립운동기지 건설 등을 활발하게 전개하고 독립 군을 양성하여 대한독립군의 봉오동전투(1920)와 북로 군정서군의 청산리대첩(1920) 등 무장투쟁을 전개하였 다. 이와 같은 역사적 간도협약의 배경과 과정을 비롯 하여 무장독립투쟁에 대하여 '선구자' 노래와 청산리 전 투 때의 '군가'를 활용한다.

\section{(2) 민족전통의 계승}

연해주지역은 발해의 옛 땅으로 발해는 고구려 유민 들이 말갈족과 함께 강력한 왕권을 바탕으로 해동성국 으로 강성하였다. 이와 같이 발해는 고구려를 계승한 유민 중심으로 돌방무덤이나 온돌양식을 비롯한 정효 공주묘 벽화 등에서 고구려의 전통방식이나 화법을 계 승한 것을 [그림 9]의 자료를 활용하여 구성한다.

\begin{tabular}{|c|c|c|}
\hline 주제 & 내용 & 시각자료 \\
\hline \multirow{3}{*}{$\begin{array}{l}\text { 독립투쟁과 } \\
\text { 민족문화게승 }\end{array}$} & $\begin{array}{l}\text { - 간도협약배경 } \\
\text { - 독립운동 } \\
\text { - 독립투쟁전개 }\end{array}$ & \\
\hline & $\begin{array}{l}\text { - 발해문화 } \\
\text { - 민족전통계승 }\end{array}$ & \\
\hline & $\begin{array}{l}\text { - 연해주지역 } \\
\text { - 정효공주묘 벽화 } \\
\text { - 문화적 연계 }\end{array}$ & \\
\hline
\end{tabular}

그림 9. 독립투쟁과 민족전통의 계승

\section{4. 한중문화유산 경관전시구축의 교육적 활용방안}

중국의 동북지역과 맞닿은 한중 경계지역의 문화유 산에 대한 연구는 우리 민족의 정체성과 역사적 문화의 식을 확립하기 위한 매우 중요하고 시급한 연구과제이 다. 이에 시각적인 자료를 이용하여 압록강과 두만강 경관에 대한 전시콘텐츠 구축방안을 [표 3]과 같이 정 리할 수 있다.

\section{표 3. 압록강 두만강지역 경관의 전시콘텐츠 구축방안}

\begin{tabular}{|c|c|c|}
\hline 구분 & 대주제 & 소주제 \\
\hline \multirow{3}{*}{$\begin{array}{l}\text { 압록강과 } \\
\text { 집안지역 }\end{array}$} & $\begin{array}{l}\text { 살아있는 고구려 } \\
\text { 문화 }\end{array}$ & $\begin{array}{l}\text {-삶의 세계 } \\
\text {-고구려 벽화, 무덤 }\end{array}$ \\
\hline & 집안의 문화유산 & $\begin{array}{l}\text {-광개토대왕릉비 } \\
\text {-고구려 천도: } \\
\text { 국내성, 환도성 }\end{array}$ \\
\hline & $\begin{array}{l}\text { 대륙을 연결하는 } \\
\text { 압록강 }\end{array}$ & $\begin{array}{l}\text {-대륙문물교류창구:연행길 } \\
\text {-근현대역사문화유산:단동 }\end{array}$ \\
\hline \multirow{3}{*}{$\begin{array}{l}\text { 두만강과 } \\
\text { 간도지역 }\end{array}$} & 백두산과 정계비 & $\begin{array}{l}\text {-백두산 } \\
\text {-백두산 정계비 }\end{array}$ \\
\hline & $\begin{array}{l}\text { 간도의 지리적 } \\
\text { 환경과 삶의 터전 }\end{array}$ & $\begin{array}{l}\text {-삶의 터전: 간도 } \\
\text {-삶의 공동체 생활 } \\
\text {-민족교육 }\end{array}$ \\
\hline & $\begin{array}{l}\text { 독립운동의 무대 } \\
\text { 인 의기의 땅 }\end{array}$ & $\begin{array}{l}\text {-간도협약 } \\
\text {-독립운동 } \\
\text {-민족전통의 계승 }\end{array}$ \\
\hline
\end{tabular}

이러한 구성은 근대의 국가에 대한 문화적 영토인식 뿐 아니라 민족의 세계문화유산에 대한 중요성을 인식 할 수 있으며 동북공정에 대한 실질적인 이해를 학습할 수 있을 것이다.

그리고 역사문화유산을 관광자원으로 활용할 수 있 을 뿐 아니라 박물관의 전시자료를 활용한 학습프로그 램의 개발에 따른 교육적 활용을 통하여 역사의식과 함 께 동북지역에 대한 한중경계지역의 문화적 특징을 이 해할 수 있을 것이다.

또한 학교의 국사교과과정이나 박물관에서 관람하는 학생들에게 시각적 자료인 고지도와 문헌을 활용하여 한중경계지역의 문화유산에 대한 이해와 역사의식을 함양할 수 있도록 [표 4]와 같이 구성하여 학습활동프 로그램으로 활용할 수 있다. 


\section{표 4. 한중경계문화유산의 박물관 학습활동방안}

\begin{tabular}{|c|c|}
\hline 학습주제 & $\begin{array}{l}\text { 지도와 문헌자료를 활용한 한중경계지역의 문화유산 } \\
\text { 이해와 역사의식 함양으로 설정한다. }\end{array}$ \\
\hline 학습목표 & $\begin{array}{l}\text { (1)박물관 전시실의 자료를 활용하여 민족문화유산을 } \\
\text { 알 수 있다. } \\
\text { (2)한중경계지역의 문화유산에 대한 이해와 체험을 통 } \\
\text { 하여 생환상을 이해 할 수 있다. } \\
\text { (3) 전시콘텐츠 구축의 필요성을 이해하고 활용방안의 } \\
\text { 중요성을 모색할 수 있다. }\end{array}$ \\
\hline 내용개요 & $\begin{array}{l}\text { (1)동서양의 고지도에 대한 이해와 우리나라의 지리적 } \\
\text { 특성을 알 수 있다. } \\
\text { (2)사진과 문헌자료를 통한 민족 문화유산의 시대적 의 } \\
\text { 미와 이해할 수 있다. } \\
\text { (3)한중경계지역의 생활민속을 이해할 수 있다. }\end{array}$ \\
\hline 준비물 & $\begin{array}{l}\text { 재료도구: 전시물, 학용품, 체험도구 } \\
\text { 기타물품; 영상시각자료, 활동지 }\end{array}$ \\
\hline & $\begin{array}{l}\text { 소개와 준비, 동기유발 } \\
\text { 전시실 관람에 대한 사전 교육 }\end{array}$ \\
\hline 도입 & $\begin{array}{l}\text { (1)동서양의 고지도에 나타난 우리나라 } \\
\text { (2)압록강과 두만강의 지리적 이해 } \\
\text { (3)우리나라와 중국의 세계문화유산 } \\
\text { (4)동북공정과 한중경계지역의 역사문화 학습 }\end{array}$ \\
\hline \multirow{3}{*}{ 전개 } & $\begin{array}{l}\text { (1)전시실 학습 } 1 \\
\text { 삼국시대와 고려시대의 한중교류 } \\
\text { 압록강과 두만강지역의 문화유산 }\end{array}$ \\
\hline & $\begin{array}{l}\text { (2)전시실 학습2 } \\
\text { 동서양에 나타난 우리나라 지도비교와 그리기 } \\
\text { 비석 탁본 체험 } \\
\text { 고분벽화이미지 문양찍기 및 목판인쇄 }\end{array}$ \\
\hline & $\begin{array}{l}\text { (3)전시실 학습3 } \\
\text { 조선과 근현대의 한중교류 } \\
\text { 는현대의 문화유산 }\end{array}$ \\
\hline 정리 & 설문지 작성과 정리 \\
\hline
\end{tabular}

\section{IV. 결론}

본 연구는 문화유산이 북한과 중국의 동북지역에 위 치하고 있는 지리적 제한과 자료 이용의 한계로 인하여 연구결과를 일반화하기에는 적지 않은 어려움이 있다. 이러함에도 불구하고 국내의 박물관이나 고등학교의 '국사'교과서에 수록된 시각자료를 분석하고 이를 바탕 으로 압록강과 두만강을 문화지리적 개념에서 문화사 적 인문경관의 전시콘텐츠를 구축하고 교육학습에 활 용하기 위한 방안을 제시한 것에 연구의 의의가 있다.

연구결과는 압록강과 집안지역의 문화유산에서 고분 벽화를 통하여 살아있는 고구려 문화와 집안의 고분에 나타난 삶의 세계 및 광개토대왕릉비 그리고 환인과 집 안지역의 문화유산과 국내성, 환도성 유적을 살펴 보았
다. 그리고 대륙을 연결하는 압록강에서는 대륙과의 문 물교류 창구인 연행길과 단동지역의 근대 역사의 문화 유산을 활용한 콘텐츠를 구성하였다. 또한 두만강과 간 도지역은 백두산과 정계비와 함께 간도의 지리적 환경 과 삶의 터전인 민족교육과 독립운동의 무대인 의기의 땅으로서 삶의 공동체 생활 모습을 구성하였다.

이와 함께 한중경계지역의 문화유산에 대한 학습방 안으로서 중고등학교 '국사'교과서의 시각적 자료 이외 에 인문 경관적인 생활사 자료를 활용하여 박물관의 학 습방안을 구성하였다.

앞으로 이러한 연구를 바탕으로 더욱 심도 깊은 연구 에 활용할 수 있는 방안을 강구할 수 있다. 첫째, 고구 려와 발해에 집중된 문화유산 뿐 아니라 조선시대와 근 현대에 이르는 한중경계지역의 문화유산으로 확장하여 전시콘텐츠로 구축하는 방안을 모색할 수 있다. 둘째, 외국인의 기록이나 사진 자료에 나타난 한중경계 지역 의 생활문화 흔적에 대한 자료정리와 콘텐츠화가 필요 하다. 셋째, 수집된 자료를 일정한 장소에 보관하고 전 시할 수 있는 박물관 공간 마련이 필요하며 압록강과 두만강 중심의 생활공간에 대한 종합적인 조사와 이를 정리하는 인문학적 연구가 필요하다. 마지막으로 중국 의 조선족과의 네트워크를 구축하여 수집한 자료를 데 이터베이스화하여 학습 자료화하고 이를 콘텐츠로 구 축하여 웹이나 앱에서 활용할 수 있는 구축방안을 강구 해야할 것이다.

이러한 노력은 한중간의 민족과 역사 그리고 동북아 의 문화적 공동체 건설을 위한 문화인식의 차이를 극복 하는 계기가 될 수 있을 것이다.

\section{참 고 문 헌}

[1] 오일환, "중국 동북3성의 한반도 문화유적에 대한 연구”, 동양학연구, 제6호, pp.75-128, 2000.

[2] 고구려연구재단, 중국의 동북변강 연구동향 분석, 2004; 국사편찬위원회, 한국 근대의 북방영토와 국경문제, 2004.

[3] 오일환, 이승수, “서양고지도를 활용한 ‘동해’전시 
콘텐츠구성 방안”, 한국콘텐츠학회논문지, 제 10 권, 제7호, pp.208-219, 2010; 오일환, “서양고지 도의 우리나라 반도형태와 한중 경계인식에 대한 연구”, 국제지역연구, 제13권, 4호, pp.327-356, 2010.

[4] 고광의, "중국의 고구려 역사문화 관광개발의 현 황과 문제점”, 고구려발해연구, 제 36 집, pp.133-172, 2010.; 안인희, “복식전시물을 활용한 박물관교육 프로그램 개발에 관한 연구-국립민속박물관 고 구려전시물을 중심으로”, 한국디자인문화학회지, 제15권, 제1호, pp.136-148, 2009.

[5] 조선통감부 간도파출소, 간도사진첩, 1908 ; 경희 대학교 혜정박물관, '영토의 경계 삶의 흔적'특별 기획전시회, 2005.

[6] 국사편찬위원회, 중학교 국사, 교사용 지도서, 교 육인적지원부, 2005; 국사편찬위원회, 고등학교 국사, 교육과학기술부, 2009.

[7] 이강원, "조선후기 국경인식에 있어서 두만강 토문강 분계강 개념과 그에 대한 검토”, 정신문화 연구, 제108호, 2007.

[8] 이화자, "광서연간 조청 양국의 을유-정해감계 에 대한 재평가“, 문화역사지리, 제 21 권, 제 1 호, pp.243-259, 2009.

[9] 김춘선, "조선인의 동북이주와 중조(한)국경문제 연구동향-중국학계의 연구성과를 중심으로”, 한 중관계사 연구의 성과와 과제, 국사편찬위원회, 2003.

\section{저 자 소 개}

\section{오 일 환(Il-Whan $\mathrm{Oh})$}

정회원

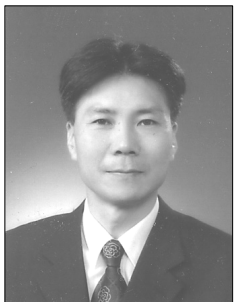

- 1984년 2월 : 경희대학교 사학과 (문학사)

- 1988년 2월 : 경희대학교 대학원 사학과(문학석사)

- 1997년 1월 : 中國 南開大學 대학 원(역사학박사)

- 2002년 현재 : 경희대학교 혜정박물관 학예연구실 장/학부대학 조교수

<관심분야> : 역사지도학, 한중사회사, 박물관학 